\title{
Editorial
}

December 1981 saw a conference - the first on this topic for some time in Britain - on women's studies and its relation to the women's liberation movement. Feminist Review has long stood for a political definition of women's studies as feminist studies, rather than as an academic specialism. In this issue we publish a discussion of these questions by Mary Evans, who argues that women's studies must always be politically radical since, in producing knowledge about women as an oppressed group, it necessarily challenges male academic assumptions. The article replies to the various criticisms made of women's studies - both from the academic world and from the women's movement - and we look forward to publishing more on this issue.

The article by Mica Nava dealing with the changing consciousness and sexual identity of young women, and the one by Mary McIntosh and Angela Weir discussing a wages strategy for women, both spring directly from current concerns of the women's liberation movement. Feminist work with young women is growing in strength and scope and having an increasingly important impact. Mica Nava's article does not attempt to give an account of all that is going on in this area but looks specifically at the experience of a small group of young women in north London, some of whom came out as lesbian and all of whom confronted the male chauvinism of their peers.

The issues explored by Mary McIntosh and Angela Weir - the relevance of trade union organization and collective bargaining to the specific needs and demands of women workers - have been simmering since women's liberation was first discussed in Britain in the late sixties. The contemporary reference for this article is a discussion of incomes policy, and the authors reject this strategy in favour of a broader struggle within the workplace but backed up by legal changes - to challenge the sexual division of labour and improve women's pay and working conditions. The article raises questions about the desirability of a 'minimum wage' and we hope these will be explored in later issues of the journal.

Jeanne Gregory's article is also concerned with the effectiveness of our equal pay and sex discrimination legislation. Whilst many writers have criticized the legislation for its weakness, there have been few studies that have looked at the obstacles a woman faces in the actual legal process of taking a case. From a survey of women who did attempt to take cases Jeanne Gregory concludes that women wanting to take legal cases need far more support in enforcing their rights. In particular, she argues that the statutory role of conciliation is often said by ACAS officers to discourage women from proceeding.

Margaret Ward's article on the suffrage movement in Ireland is a historical account with greater than usual relevance to contemporary politics. For a brief moment the struggle for the vote created a basis for unity among women north and south of the border. But in the long-term the divisions generated in the conflict over nationalism and unionism made it impossible for a united and independent women's position to emerge. 
We also publish in this issue an article by Janet Sayers in response to an earlier piece we published on psychoanalysis. We are soliciting alternative points of view on this debate and will continue to publish on this quesion.

Most of the articles in this issue of Feminist Review - if not all of them - are politically controversial. We make no apology for this, indeed we see the journal as useful in provoking debate among feminists on contentious issues. If you disagree with an article, please write and say so. The Feminist Review collective obviously takes responsibility for the choice of questions raised in the journal. It also takes decisions on who it publishes and we know that some feminists disagree with these decisions. (For example, we do not publish work by men, but we do allow heterosexual women to write about lesbians and vice-versa.) The specific arguments made in articles are, however, the responsibility of their authors and not necessarily of Feminist Review as a journal. We might add that this applies - no more and no less - to members of the collective when they publish in the journal.

\section{Fund Drive}

Readers of our editorials will know that we usually include some ritual comments on our precarious financial situation. You will be pleased to hear that we have now decided to DO something about it.

The present situation is that we run on the proverbial shoestring, which basically means a lot of unpaid labour. We keep the individual subscription price as low as possible and in effect we run at a loss. If we increased our circulation we would be on a much firmer financial footing and we know we could do this if we had the time and resources to put into it.

What we plan is a calculated risk. We are going for a much more positive marketing and distribution strategy, aimed at getting more subscriptions both here and abroad. To do this we need to rent an office, increase the hours of our part-time worker and put money into publicity and advertising. This will cost us over $£ 10,000$ (ten thousand pounds) spread over the next two years and by the end of 1983 will mean that we are financially viable.

You can belp in two ways.

1 Subscribe yourself and get your friends to. Persuade your local library to subscribe. (Some public libraries do, as well as many college libraries - we can send a sample copy if they ask for one.)

2 If you can afford it - and we think it is right for better-off readers to subsidize the price of the journal - contribute to our Target of $£ 10,000$ in our Fund Drive by

sending a donation now

- becoming a sustaining subscriber when you renew your sub (£25)

- making out a banker's order to us for a regular monthly donation (we can send you the form)

\section{Feminist Review Conference}

Saturday March 13th

Feminism and the Political Crisis of the 1980s

Venue (in London) and details to be announced in Spare Rib

Women only. 